\title{
Theories of behaviour change synthesised into a set of theoretical groupings: introducing a thematic series on the theoretical domains framework
}

\author{
Jill J Francis ${ }^{1 *}$, Denise O'Connor ${ }^{2}$ and Janet Curran ${ }^{3}$
}

\begin{abstract}
Behaviour change is key to increasing the uptake of evidence into healthcare practice. Designing behaviour-change interventions first requires problem analysis, ideally informed by theory. Yet the large number of partly overlapping theories of behaviour makes it difficult to select the most appropriate theory. The need for an overarching theoretical framework of behaviour change was addressed in research in which 128 explanatory constructs from 33 theories of behaviour were identified and grouped. The resulting Theoretical Domains Framework (TDF) appears to be a helpful basis for investigating implementation problems. Research groups in several countries have conducted TDF-based studies. It seems timely to bring together the experience of these teams in a thematic series to demonstrate further applications and to report key developments. This overview article describes the TDF, provides a brief critique of the framework, and introduces this thematic series.

In a brief review to assess the extent of TDF-based research, we identified 133 papers that cite the framework. Of these, 17 used the TDF as the basis for empirical studies to explore health professionals' behaviour. The identified papers provide evidence of the impact of the TDF on implementation research. Two major strengths of the framework are its theoretical coverage and its capacity to elicit beliefs that could signify key mediators of behaviour change. The TDF provides a useful conceptual basis for assessing implementation problems, designing interventions to enhance healthcare practice, and understanding behaviour-change processes. We discuss limitations and research challenges and introduce papers in this series.
\end{abstract}

\section{Background}

Behaviour change is key to increasing the uptake of evidence into healthcare practice. Behavioural science in general, and health psychology in particular, abounds with plausible, evidence-based theories and models that purport to explain and predict behaviour and behaviour change. It makes sense to design interventions on the basis of such models. However, to the multidisciplinary implementation research community and, often, to health psychologists as well, there is a bewildering array of theories from which to choose. Selecting one theory or a few theories as the basis for intervention design

\footnotetext{
* Correspondence: j.francis@abdn.ac.uk

${ }^{1}$ Health Psychology Group and Health Services Research Unit, University of

Aberdeen, Aberdeen, UK

Full list of author information is available at the end of the article
}

leaves the researcher (or reviewer) in doubt as to whether some key factor may have been omitted. The need for an overarching theoretical framework has been addressed in an influential line of research in which 128 explanatory constructs from 33 theories of behaviour were identified [1]. Key constructs relevant to changing the behaviour of healthcare professionals were grouped into 12 'theoretical construct domains'. The 12 domains are labelled (1) Knowledge; (2) Skills; (3) Social/Professional Role and Identity; (4) Beliefs about Capabilities; (5) Beliefs about Consequences; (6) Motivation and Goals; (7) Memory, Attention, and Decision Processes; (8) Environmental Context and Resources; (9) Social Influences; (10) Emotion; (11) Behavioural Regulation; and (12) Nature of the Behaviours. The resulting Theoretical Domains Framework (TDF) has been used in a 
variety of contexts to inform and address implementation problems.

Interview questions and questionnaire items may be designed to explore the specific content of these domains in relation to implementation problems. The TDF may also be used as a coding framework for analysis. The theoretical domains are proposed to be potential mediators of behaviour change (except for Nature of the Behaviours, which is accorded a different status to the rest, as it relates to the essential characteristics of the behaviour of interest rather than possible mediating mechanisms or influences on behaviour). Each domain consists of a grouping of theoretical constructs (where constructs are defined as component parts of theories, such as 'attitude', 'selfefficacy', 'anxiety'). For example, the domain Social Influences includes such constructs as social support, group norms, group conformity, social pressure, social comparisons, and several others [1]. In this example domain, the pertinent constructs are grouped together to represent the influences of people on others' behaviours.

Further consensus work has identified some of the behaviour-change techniques that are likely to be effective (and others that are likely to be ineffective) if they target specific domains when these domains are identified as likely mediators of change [2]. The 12 theoretical construct domains thus represent a large range of theoretical approaches and can be used for problem analysis, theorising pathways of change, designing interventions, identifying appropriate process measures, and testing pathways to change [1].

\section{Objectives of the thematic series}

At this time, over 6 years after the publication of the original TDF paper [1], it is timely to document the impact of this framework on implementation research and to consider its strengths, limitations, and potential for further use and development. This article provides a brief overview of the TDF and serves as an introduction to a thematic series on the TDF for Implementation Science. Research groups from several countries, exploring a variety of implementation problems, have contributed to this series in order to

(1) demonstrate the breadth of behaviours, clinical settings, designs, and methods that have used the TDF;

(2) explain how the TDF can be applied and operationalised to explore implementation problems and design implementation interventions;

(3) describe theoretical and methodological developments based on the TDF;

(4) raise questions that may suggest an agenda for future TDF research.

\section{Utilisation of the theoretical domains framework in implementation research}

To document the impact of the TDF on implementation research to date, we conducted a brief indicative review. We searched the abstracts (and full text, if required, for clarity) of all papers citing the paper that described the development of the TDF [1] to 30 November 2011 (identified through www.scopus.com). We selected, for further description, the studies that used the TDF as the basis for an empirical study. We noted the range of journals in which these studies were published, the countries in which the studies were conducted, the behaviours investigated, and the study designs used. Where relevant for identifying impact or validity, we also extracted the specific findings or methods reported in these studies.

Of the 133 citing papers (from 83 scientific journals) indexed in the Scopus database, 23 papers reporting 21 different studies used the TDF as the basis for an empirical study. Where a study protocol and a results paper were published with respect to the same study, we included only the results paper. Of the 21 studies identified, 17 investigated the behaviour of health professionals and four investigated health-related behaviour of members of the public. Ten of the 21 studies described exploratory interview studies (with individuals or focus groups) designed to identify barriers and levers to uptake of a guideline [3-13], often to inform intervention design. Two reports described questionnaire studies $[13,14]$, and two reported both interviews and questionnaires $[15,16]$. There were four systematic reviews in which the theoretical domains were investigated as mediators of behaviour change [17-20], two randomised studies [21,22], and one protocol for a process evaluation study to explain trial effects in the context of a randomised trial [23]. The included studies provide evidence that the TDF has considerable breadth and cross-disciplinary impact in research about healthrelated behaviour (studies were published in 13 journals) and geographical reach (six countries from four continents were represented). Table 1 presents a summary of the characteristics of studies that have used the TDF to investigate health behaviours.

Papers excluded from further description were editorials and opinion pieces, empirical studies in which the TDF was used to support an aspect of the rationale, and empirical studies based on other theories in which the TDF was cited in the discussion of the study findings.

\section{Discussion and critique}

The TDF appears to have succeeded in 'making psychological theory useful' to researchers from a variety of disciplinary backgrounds internationally, to investigate a wide range of behaviours in various healthcare settings. The great majority of the identified papers report 
Table 1 Summary characteristics of studies citing the original Theoretical Domains Framework (TDF) paper that used the framework in an empirical study

\begin{tabular}{|c|c|c|c|c|}
\hline Lead author, source, date & Paper title & Study design of TDF-based component & Sample & Behaviour; setting \\
\hline $\begin{array}{l}\text { Jacobs N. Patient } \\
\text { Education \& } \\
\text { Counseling } \\
\text { 2011:85(1);122 }\end{array}$ & $\begin{array}{l}\text { Effect of a cardiovascular prevention } \\
\text { program on health behaviour and BMI in } \\
\text { highly educated adults: A randomized } \\
\text { controlled trial }\end{array}$ & $\begin{array}{l}\text { Randomised } \\
\text { controlled trial }\end{array}$ & $\begin{array}{l}\text { Highly educated adults } \\
(n=314)\end{array}$ & $\begin{array}{l}\text { Fat intake, physical } \\
\text { activity, smoking; } \\
\text { Belgium }\end{array}$ \\
\hline $\begin{array}{l}\text { Amemori M. } \\
\text { Implementation } \\
\text { Science 2011:6(1); } 50\end{array}$ & $\begin{array}{l}\text { Assessing implementation difficulties in } \\
\text { tobacco use prevention and cessation } \\
\text { counselling among dental providers }\end{array}$ & Questionnaire study & $\begin{array}{l}\text { Dental healthcare providers } \\
(n=73)\end{array}$ & $\begin{array}{l}\text { Providing tobacco } \\
\text { use prevention } \\
\text { techniques and } \\
\text { cessation } \\
\text { counselling; } \\
\text { Finland }\end{array}$ \\
\hline $\begin{array}{l}\text { Zhu D. Obesity } \\
\text { Reviews } \\
\text { 2011:12(501);e324 }\end{array}$ & $\begin{array}{l}\text { The relationship between health } \\
\text { professionals' weight status and attitudes } \\
\text { towards weight management: A systematic } \\
\text { review }\end{array}$ & Systematic review & $\begin{array}{l}\text { Health professionals from } 14 \\
\text { independent samples } \\
(n=10,043)\end{array}$ & $\begin{array}{l}\text { Providing weight } \\
\text { management advice }\end{array}$ \\
\hline $\begin{array}{l}\text { Helms C. Vaccine } \\
\text { 2011:29(16);2895 }\end{array}$ & $\begin{array}{l}\text { Implementation of mandatory immunisation } \\
\text { of healthcare workers: Observations from } \\
\text { New South Wales, Australia }\end{array}$ & Interview study & $\begin{array}{l}\text { Stakeholders from health department, } \\
\text { hospitals, health professional } \\
\text { associations, universities } \\
(n=58)\end{array}$ & $\begin{array}{l}\text { Immunisation of } \\
\text { healthcare workers; } \\
\text { Australia }\end{array}$ \\
\hline $\begin{array}{l}\text { Dyson J. Journal of } \\
\text { Infection Prevention } \\
\text { 2011:12(1);17 }\end{array}$ & $\begin{array}{l}\text { Does the use of a theoretical approach tell } \\
\text { us more about hand hygiene behaviour? } \\
\text { The barriers and levers to hand hygiene }\end{array}$ & $\begin{array}{l}\text { Interviews, focus } \\
\text { groups, and } \\
\text { questionnaire study }\end{array}$ & $\begin{array}{l}\text { Healthcare practitioners } \\
\text { ( } n=25,21,24 \text { for interviews, focus } \\
\text { groups, and questionnaire, } \\
\text { respectively) }\end{array}$ & $\begin{array}{l}\text { Hand hygiene } \\
\text { behaviours; UK }\end{array}$ \\
\hline $\begin{array}{l}\text { Ivers NM. } \\
\text { Implementation } \\
\text { Science 2010:5(1); } 98\end{array}$ & $\begin{array}{l}\text { Feedback GAP: Study protocol for a } \\
\text { cluster-randomized trial of goal setting and } \\
\text { action plans to increase the effectiveness of } \\
\text { audit and feedback interventions in } \\
\text { primary care }\end{array}$ & $\begin{array}{l}\text { Protocol for process } \\
\text { evaluation, involving } \\
\text { interviews, to } \\
\text { investigate barriers to } \\
\text { change in trial context }\end{array}$ & $\begin{array}{l}\text { Primary care practitioners } \\
\text { (target } n=12 \text { ) }\end{array}$ & $\begin{array}{l}\text { Primary care; } \\
\text { Canada }\end{array}$ \\
\hline $\begin{array}{l}\text { Cuthbertson B. Trials } \\
\text { 2010:11; } 117\end{array}$ & $\begin{array}{l}\text { A study of the perceived risks, benefits and } \\
\text { barriers to the use of SDD in adult critical } \\
\text { care units (the SuDDICU study) }\end{array}$ & $\begin{array}{l}\text { Protocol for } \\
\text { multistage feasibility } \\
\text { study involving } \\
\text { interviews for a } \\
\text { Delphi study }\end{array}$ & $\begin{array}{l}\text { Four stakeholder groups involved in } \\
\text { intensive care (critical care, infectious } \\
\text { diseases, pharmacy, nursing) } \\
\text { (target } n=120 \text { ) }\end{array}$ & $\begin{array}{l}\text { Provision of } \\
\text { Selective } \\
\text { Decontamination of } \\
\text { the Digestive Tract } \\
\text { (SDD) in Critical } \\
\text { Care; UK, Canada, } \\
\text { Australia, New Zealand }\end{array}$ \\
\hline $\begin{array}{l}\text { McKenzie JE. } \\
\text { Implementation } \\
\text { Science 2010:5(1); } 86\end{array}$ & $\begin{array}{l}\text { Improving the care for people with acute } \\
\text { low-back pain by allied health professionals } \\
\text { (the ALIGN trial): A cluster randomised } \\
\text { trial protocol }\end{array}$ & $\begin{array}{l}\text { Protocol includes } \\
\text { interviews; findings } \\
\text { used to design } \\
\text { intervention }\end{array}$ & $\begin{array}{l}\text { Physiotherapists and chiropractors in } \\
\text { Australia } \\
\text { (210 practices) }\end{array}$ & $\begin{array}{l}\text { Behaviours from a } \\
\text { clinical practice } \\
\text { guideline for acute } \\
\text { low back pain; } \\
\text { Australia }\end{array}$ \\
\hline $\begin{array}{l}\text { Hetrick S. } \\
\text { Australasian } \\
\text { Psychiatry } \\
\text { 2010:18(5);451 }\end{array}$ & $\begin{array}{l}\text { Promoting physical health in youth mental } \\
\text { health services: Ensuring routine } \\
\text { monitoring of weight and metabolic indices } \\
\text { in a first episode psychosis clinic }\end{array}$ & Interview study & $\begin{array}{l}\text { Psychiatrists } \\
\text { (n not reported) }\end{array}$ & $\begin{array}{l}\text { Monitoring of } \\
\text { weight gain and } \\
\text { metabolic indices } \\
\text { in people with first } \\
\text { episode psychosis; } \\
\text { Australia }\end{array}$ \\
\hline
\end{tabular}


Table 1 Summary characteristics of studies citing the original Theoretical Domains Framework (TDF) paper that used the framework in an empirical study (Continued)

\begin{tabular}{|c|c|c|c|c|}
\hline $\begin{array}{l}\text { Brotherton JML. } \\
\text { Sexual Health } \\
\text { 2010:7(3):291 }\end{array}$ & $\begin{array}{l}\text { National survey of general practitioners' } \\
\text { experience of delivering the national human } \\
\text { papillomavirus vaccination (HPV) program }\end{array}$ & Questionnaire study & $\begin{array}{l}\text { General practitioners } \\
(n=298)\end{array}$ & $\begin{array}{l}\text { Delivery of HPV } \\
\text { vaccine, general } \\
\text { practice; Australia }\end{array}$ \\
\hline $\begin{array}{l}\text { Clarkson JE. } \\
\text { Implementation } \\
\text { Science 2010:5(1);57 }\end{array}$ & $\begin{array}{l}\text { The translation research in a dental setting } \\
\text { (TRiaDS) programme protocol }\end{array}$ & $\begin{array}{l}\text { Questionnaires and } \\
\text { interviews used to } \\
\text { develop interventions }\end{array}$ & $\begin{array}{l}\text { Range of samples, } \\
\text { dentistry staff }\end{array}$ & $\begin{array}{l}\text { Range of dental } \\
\text { care behaviours; } \\
\text { UK }\end{array}$ \\
\hline $\begin{array}{l}\text { Edwards P. BMC } \\
\text { Public Health } \\
\text { 2010:10;200 }\end{array}$ & $\begin{array}{l}\text { Assessing the effectiveness and } \\
\text { cost-effectiveness of adaptive e-Learning } \\
\text { to improve dietary behaviour: Protocol for } \\
\text { a systematic review }\end{array}$ & Systematic review & Participants aged 13 years or over & Dietary behaviour \\
\hline $\begin{array}{l}\text { Guillaimie L. } \\
\text { International Journal } \\
\text { of Behavioral } \\
\text { Nutrition \& Physical } \\
\text { Activity 2010:7;12. }\end{array}$ & $\begin{array}{l}\text { Psychosocial determinants of fruit and } \\
\text { vegetable intake in adult population: } \\
\text { A systematic review }\end{array}$ & Systematic review & General population $(\mathrm{n}=34,577)$ & $\begin{array}{l}\text { Fruit and } \\
\text { vegetable intake }\end{array}$ \\
\hline $\begin{array}{l}\text { McCluskey A. BMC } \\
\text { Health Services } \\
\text { Research 2010:10;18 }\end{array}$ & $\begin{array}{l}\text { Delivering an evidence-based outdoor } \\
\text { journey intervention to people with stroke: } \\
\text { Barriers and enablers experienced by } \\
\text { community rehabilitation teams }\end{array}$ & $\begin{array}{l}\text { Before-after interview } \\
\text { study }\end{array}$ & $\begin{array}{l}\text { Allied health professionals from two } \\
\text { rehabilitation teams } \\
(n=13)\end{array}$ & $\begin{array}{l}\text { Delivery of } \\
\text { evidence-based } \\
\text { outdoor journey } \\
\text { intervention for } \\
\text { people with stroke; } \\
\text { Australia }\end{array}$ \\
\hline $\begin{array}{l}\text { Nzinga J. } \\
\text { Implementation } \\
\text { Science 2010:4(1); } 44\end{array}$ & $\begin{array}{l}\text { Documenting the experiences of health } \\
\text { workers expected to implement guidelines } \\
\text { during an intervention study in Kenyan } \\
\text { hospitals }\end{array}$ & Interview study & $\begin{array}{l}\text { Health workers } \\
(n=29)\end{array}$ & $\begin{array}{l}\text { Paediatric and } \\
\text { newborn care in } \\
\text { hospitals; Kenya }\end{array}$ \\
\hline $\begin{array}{l}\text { Godin G. } \\
\text { Implementation } \\
\text { Science 2010:3(1); } 36\end{array}$ & $\begin{array}{l}\text { Healthcare professionals' intentions and } \\
\text { behaviours: A systematic review of studies } \\
\text { based on social cognitive theories }\end{array}$ & Systematic review & $\begin{array}{l}\text { Studies of health professionals' } \\
\text { behaviour } \\
(n=78)\end{array}$ & $\begin{array}{l}\text { Studies based on } \\
\text { social cognitive } \\
\text { theories }\end{array}$ \\
\hline $\begin{array}{l}\text { Francis JJ. British } \\
\text { Journal of Health } \\
\text { Psychology } \\
\text { 2009:14(4);625 }\end{array}$ & $\begin{array}{l}\text { Evidence-based selection of theories for } \\
\text { designing behaviour change interventions: } \\
\text { Using methods based on theoretical } \\
\text { construct domains to understand clinicians' } \\
\text { blood transfusion behaviour }\end{array}$ & Interview study & $\begin{array}{l}\text { Intensive care consultants and } \\
\text { neonatologists } \\
(n=18)\end{array}$ & $\begin{array}{l}\text { Intensive care and } \\
\text { paediatric intensive } \\
\text { care; UK }\end{array}$ \\
\hline $\begin{array}{l}\text { Judah G. American } \\
\text { Journal of Public } \\
\text { Health } \\
\text { 2009:99(Suppl.2) }\end{array}$ & $\begin{array}{l}\text { Experimental pretesting of hand-washing } \\
\text { interventions in a natural setting }\end{array}$ & $\begin{array}{l}\text { Naturalistic } \\
\text { randomised study; } \\
\text { hour of the day as unit } \\
\text { of randomisation }\end{array}$ & $\begin{array}{l}\text { General population } \\
\text { ( } n=\text { nearly } 200,000 \text { restroom uses) }\end{array}$ & $\begin{array}{l}\text { Hand washing in } \\
\text { public restrooms; } \\
\text { UK }\end{array}$ \\
\hline $\begin{array}{l}\text { Pitt VJ. Disability \& } \\
\text { Rehabilitation } \\
\text { 2008:30(25);1938 }\end{array}$ & $\begin{array}{l}\text { Referral of people with osteoarthritis to } \\
\text { self-management programmes: Barriers and } \\
\text { enablers identified by general practitioners }\end{array}$ & Interview study & $\begin{array}{l}\text { General practitioners } \\
(n=13)\end{array}$ & $\begin{array}{l}\text { Referral of people } \\
\text { with osteoarthritis } \\
\text { to self-management } \\
\text { programmes; } \\
\text { Australia }\end{array}$ \\
\hline
\end{tabular}

ourney intervention to people with stroke: Barriers and enablers experienced by

Documenting the experiences of health workers expected to implement guidelines hospitals social cognitive theories

blood transfusion behaviour

Experimental pretesting of hand-washing

Referral of people with osteoarthritis to

self-management programmes: Barriers and

randomised study;

ur of the day as unit

interview study

General practitioners

programmes; 
Table 1 Summary characteristics of studies citing the original Theoretical Domains Framework (TDF) paper that used the framework in an empirical study (Continued)

\begin{tabular}{|c|c|c|c|c|}
\hline $\begin{array}{l}\text { McKenzie JE. } \\
\text { Implementation } \\
\text { Science 2008:3(1); } 11\end{array}$ & $\begin{array}{l}\text { IMPLEmenting a clinical practice guideline } \\
\text { for acute low back pain evidence-based } \\
\text { manageMENT in general practice } \\
\text { (IMPLEMENT): Cluster randomised } \\
\text { controlled trial study protocol }\end{array}$ & $\begin{array}{l}\text { Protocol includes } \\
\text { focus group } \\
\text { interviews; findings } \\
\text { used to design } \\
\text { intervention }\end{array}$ & $\begin{array}{l}\text { General practitioners } \\
\text { (target sample } \\
\text { size }=92 \text { general practices) }\end{array}$ & $\begin{array}{l}\text { Behaviours from a } \\
\text { clinical practice } \\
\text { guideline for acute } \\
\text { low back pain; } \\
\text { Australia }\end{array}$ \\
\hline $\begin{array}{l}\text { Michie S. } \\
\text { Implementation } \\
\text { Science 2007:2(1); } 8\end{array}$ & $\begin{array}{l}\text { Difficulties implementing a mental health } \\
\text { guideline: An exploratory investigation } \\
\text { using psychological theory }\end{array}$ & Interview study & $\begin{array}{l}\text { Professionals in community mental } \\
\text { health teams } \\
(n=20)\end{array}$ & $\begin{array}{l}\text { Offering a family } \\
\text { intervention to } \\
\text { families of people } \\
\text { with schizophrenia; } \\
\text { UK }\end{array}$ \\
\hline
\end{tabular}

BMI body mass index; GAP goal setting and action plans; SUDDICU selective decontamination of the digestive tract in intensive care units; ALIGN acute low-back pain: implementing guidelines iNto practice. 
implementation research, and half of the identified papers report interview studies. Critics of the TDF might argue that an interview topic guide based on the framework is too focused and too constraining and would lead participants to select only the views and opinions about the topic that fit into the framework. However, one study used randomised designs to make direct comparisons of results when methods were based on the TDF versus atheoretical methods, using interviews, focus groups, and a questionnaire [16]. Although there was considerable overlap in the findings from the two approaches, the TDF-based studies elicited beliefs that were not mentioned in the studies that had no theoretical basis. Furthermore, the data generated using the TDF approach were more likely to elicit beliefs about the impact of emotional factors on behaviours, demonstrating that the framework does not limit its investigation to rational or 'cognitive' processes [16]. This suggests that the theoretical coverage of the TDF is comprehensive and that it can facilitate an inclusive, rather than selective, approach to exploratory research in the field of implementation.

Hence, two major strengths of the TDF are its theoretical coverage and its capacity to elicit a comprehensive set of beliefs that could potentially be mediators of behaviour change. In its current form and as currently used, one limitation is that it is a descriptive framework rather than a theory, that is, it does not specify relationships between the domains [9] and thus does not generate testable hypotheses. Another limitation relates to the fact that the majority of studies to date have used the TDF in interview studies (Table 1), which are characterised by the problem that data collected from an interview reflect participants' attributions about the influences on their behaviours, including possible attributional biases [24,25], and may not necessarily reflect 'actual' causes. However, this limitation is a function of the research designs that are frequently used in TDFbased studies rather than a limitation of the framework itself. In the context of interview studies, a further limitation is that inter-coder agreement can be relatively low [9], perhaps reflecting a difficulty that some research teams have in clarifying the boundaries between domains when the TDF is used as a coding framework.

It is perhaps appropriate to offer a word of warning to researchers who wish to base their research on the TDF. The domains integrate theoretical constructs that have been developed during the course of a century of theory-focused, empirical research in behavioural science. This is both a strength and a weakness of the TDF. It is a weakness insofar as the depth of meaning of the domains may not be evident to researchers without training or experience in behavioural theory, so there is the potential for the TDF to be poorly or superficially applied. To use the framework effectively, researchers need to 'dig deep', beyond a superficial interpretation of the domains. Thus, interdisciplinary research teams using the TDF for the first time may benefit from the inclusion of a health psychologist on the team. On the other hand, a strength is that there is a wealth of evidence relating to these domains that can facilitate researchers to finesse their exploratory research and to map the results of TDF-based problem analysis on to intervention components. We would argue that this is an effective way to build a solid rationale for implementation interventions.

\section{Potential for further elaboration of the theoretical domains}

Although the TDF was developed to represent theories of organisational behaviour as well as individual behaviour, some researchers interested in organisational-level factors may feel that such factors are not adequately elaborated in the framework. Domains that arguably focus on these levels are Environmental Context and Resources, Social Influences, Social/Professional Role and Identity, and Behavioural Regulation. Table 2 presents some examples of constructs in these four domains in the TDF [1] that represent the team or organisational levels and shows that several organisational constructs are indeed represented. Furthermore, it may be helpful here to distinguish between the level at which an intervention may be delivered (e.g., incentives offered by the government to general practitioners for recording blood pressure readings of people with diabetes) and the level at which evidence of its impact may be measured (individual general practitioners more frequently record blood pressure readings). Hence, there appears to be reasonable representation in the framework of organisational factors that are relevant to clinical behaviours, although it is likely that further elaboration would enhance the usefulness of the framework for researchers interested in organisational-level influences.

Nonetheless, some organisational theories are not concerned with the clinical actions performed by healthcare workers in the process of delivering healthcare. For example, Karasek's Job Control Model [26] focuses on outcomes such as burnout, staff turnover, job satisfaction, and the like. Although these outcomes are important issues in their own right and are arguably related to the quality of healthcare provided, they are different from the actions of healthcare workers as they deliver healthcare and so are beyond the scope of the TDF. Thus, not all organisational theories are appropriate for inclusion in the framework.

The domain Nature of the Behaviour is often omitted in TDF-based studies, with the reasoning that it relates more to an understanding of the characteristics of the 
Table 2 Constructs in four theoretical domains, illustrating individual, team, and organisational levels (based on construct allocations reported by Michie et al [1])

\begin{tabular}{|c|c|c|c|}
\hline \multirow[t]{2}{*}{ Domain } & \multicolumn{3}{|c|}{ Level } \\
\hline & Individual & Team & Organisation \\
\hline $\begin{array}{l}\text { Environmental } \\
\text { Context and } \\
\text { Resources }\end{array}$ & $\begin{array}{l}\text { Environmental } \\
\text { stressors } \\
\text { Person } \times \text { environment } \\
\text { interaction }\end{array}$ & $\begin{array}{l}\text { Environmental } \\
\text { stressors }\end{array}$ & $\begin{array}{l}\text { Resources/material } \\
\text { resources (availability } \\
\text { and management) }\end{array}$ \\
\hline Social Influences & $\begin{array}{l}\text { Social support } \\
\text { Social pressure }\end{array}$ & $\begin{array}{l}\text { Leadership } \\
\text { Social comparisons }\end{array}$ & $\begin{array}{l}\text { Organisational climate/culture } \\
\text { Change management }\end{array}$ \\
\hline $\begin{array}{l}\text { Social/Professional } \\
\text { Role and Identity }\end{array}$ & $\begin{array}{l}\text { Identity } \\
\text { Professional identity }\end{array}$ & $\begin{array}{l}\text { Professional } \\
\text { boundaries/role } \\
\text { Group/social identity }\end{array}$ & Organisational commitment \\
\hline $\begin{array}{l}\text { Behavioural } \\
\text { Regulation }\end{array}$ & $\begin{array}{l}\text { Goal/target setting } \\
\text { Self-monitoring }\end{array}$ & $\begin{array}{l}\text { Goal/target setting } \\
\text { Self-monitoring }\end{array}$ & $\begin{array}{l}\text { Goal/target setting } \\
\text { Barriers and facilitators }\end{array}$ \\
\hline
\end{tabular}

behaviour itself than to influences on behaviour [13]. However, it may be worth considering the wealth of research following the Diffusion of Innovations approach [27] suggesting that the nature of the innovation (i.e., the behaviour(s) targeted for change) can have a large impact on its adoption. Inclusion of key factors (e.g., is the target behaviour complex, observable, trialable, high profile [28]) could render this domain highly relevant for designing interventions and predicting behaviour change.

\section{Links between the theoretical domains framework and other frameworks}

The TDF is potentially compatible with a range of existing frameworks in the implementation literature. For example, Kitson and colleagues [29] called for the integration of theoretical perspectives into the Promoting Action on Research in Health Services (PARiHS) framework. The TDF could be useful in elaborating some components of the 'diagnostic and evaluation' stage of PARiHS. Damschroder and colleagues [30] proposed a Consolidated Framework for Implementation Research (CFIR); there is potential for mapping the TDF domains on to constructs in this framework (in particular, within Outer Setting, Inner Setting, and Characteristics of Individuals). The advantage of such a process would be to provide access to a large evidence base from the behaviour-change literature that could be useful in CFIR-based research.

Further potential of the theoretical domains framework in implementation research

The TDF is amenable to application in study designs other than interview and questionnaire studies. For example, it may be used as a conceptual framework to guide structured observation of the target group and/or supplementary data collection from other stakeholders (that is, others affected by performance/nonperformance of behaviour, such as patients or colleagues). TDF-based interview and observational studies may thus be seen as hypothesis-generating investigations that are appropriate in the earlier, exploratory phases of an implementation research programme.

\section{The theoretical domains framework thematic series}

In this TDF thematic series, a number of papers report exploratory research with respect to a range of clinical behaviours that, evidence suggests, should change so that gains can be made in quality of healthcare and patient outcomes. Other papers in the series illustrate methods that can be used when applying the TDF to problem analysis, intervention design, and process evaluation. Such approaches are consistent with calls for more systematic methods of developing interventions, specifying the 'active ingredients' of interventions and theorising the pathways to change $[31,32]$.

The TDF was formulated to enhance the usefulness of behavioural theory to researchers in a range of disciplines. Its success in generating research and contributing to problem solving in implementation research could be seen as a confirmation of its usefulness. Nonetheless, further interrogation, validation, and refinement would seem appropriate. A key paper in this series reports a validation study that independently assesses the structure of the framework [33].

\section{Conclusion}

The TDF describes a comprehensive range of potential mediators of behaviour change relating to clinical actions. It thus provides a useful conceptual basis for exploring implementation problems, designing implementation interventions to enhance healthcare practice, and understanding behaviour-change processes in the implementation of evidence-based care. Nonetheless, some unresolved issues remain. These include the relationships between the theoretical domains, possible lack of precision of boundaries between domains, how best to elaborate and operationalise the framework, how best to 
design interventions informed by TDF-based problem analysis, and how best to accumulate evidence to refine the content of the framework. There are opportunities for further international collaborative research to address these issues.

\section{Competing interests}

DO is an Associate Editor of Implementation Science. All editorial decisions regarding this article and all subsequent articles in the TDF series were made independently by Robbie Foy, Deputy Editor-in-Chief.

\section{Authors' contributions}

JJF drafted the initial form and all revisions of this manuscript. JC and DO provided input, feedback, and substantial refinements. All authors agreed to the final manuscript.

\section{Acknowledgements}

JJF is funded by the Chief Scientist Office of the Scottish Government Health Directorates. DO holds an Australian NHMRC Public Health Fellowship (606726). JC holds a Canadian Institute of Health Research (CIHR) Postdoctoral Fellowship.

\section{Author details}

'Health Psychology Group and Health Services Research Unit, University of Aberdeen, Aberdeen, UK. ${ }^{2}$ School of Public Health and Preventive Medicine, Monash University, Victoria, Australia. ${ }^{3}$ Clinical Epidemiology Program, Ottawa Hospital Research Institute, University of Ottawa, Ottawa, Canada.

Received: 22 December 2011 Accepted: 12 March 2012 Published: 24 April 2012

\section{References}

1. Michie S, Johnston M, Abraham C, Lawton R, Parker D, Walker A "Psychological Theory" Group: Making psychological theory useful for implementing evidence based practice: a consensus approach. Qual Saf Health Care 2005, 14(1):26-33.

2. Michie S, Johnston M, Francis JJ, Hardeman W. Eccles MP: From theory to intervention: mapping theoretically derived behavioural determinants to behaviour change techniques. Appl Psychol: Int Rev 2008, 57:660-680.

3. Helms C, Leask J, Robbins SC, Chow MYK, McIntyre P: Implementation of mandatory immunisation of healthcare workers: observations from New South Wales, Australia. Vaccine 2011, 29(16):2895-2901.

4 Cuthbertson BH, Francis J, Campbell MK, Maclntyre L, Seppelt I, Grimshaw J: A study of the perceived risks, benefits and barriers to the use of SDD in adult critical care units (The SuDDICU study). Trials 2010, 11:117.

5. McKenzie JE, O'Connor DA, Page MJ, Mortimer DS, French SD, Walker BF, Keating JL, Grimshaw JM, Michie S, Francis JJ, Green SE: Improving the care for people with acute low-back pain by allied health professionals (the ALIGN trial): a cluster randomised trial protocol. Implementation Science 2010, 5(1).

6. Hetrick S, Álvarez-Jiménez M, Parker A, Hughes F, Willet M, Morley K, Fraser R, McGorry PD, Thompson A: Promoting physical health in youth mental health services: ensuring routine monitoring of weight and metabolic indices in a first episode psychosis clinic. Australas Psychiatry 2010, 18(5):451-455.

7. McCluskey A, Middleton S: Delivering an evidence-based outdoor journey intervention to people with stroke: Barriers and enablers experienced by community rehabilitation teams. BMC Health Services Research 2010, 10:18.

8. Nzinga J, Mbindyo P, Mbaabu L, Warira A, English M: Documenting the experiences of health workers expected to implement guidelines during an intervention study in Kenyan hospitals. Implementation Science 2009, 4:44.

9. Francis JJ, Stockton C, Eccles MP, Johnston M, Cuthbertson BH, Grimshaw JM, Hyde C, Tinmouth A, Stanworth SJ: Evidence-based selection of theories for designing behaviour change interventions: using methods based on theoretical construct domains to understand clinicians' blood transfusion behaviour. Br J Heal Psychol 2009, 14(4):625-646.

10. Pitt VJ, O'Connor D, Green S: Referral of people with osteoarthritis to selfmanagement programmes: barriers and enablers identified by general practitioners. Disabil Rehabil 2008, 30(25):1938-1946.
11. McKenzie JE, French SD, O'Connor DA, Grimshaw JM, Mortimer D, Michie S, Francis J, Spike N, Schattner P, Kent PM, Buchbinder R, Green SE IMPLEmenting a clinical practice guideline for acute low back pain evidence-based manageMENT in general practice (IMPLEMENT): cluster randomised controlled trial study protocol. Implementation Science 2008, 3:11.

12. Michie S, Pilling S, Garety P, Whitty P, Eccles MP, Johnston M, Simmons J: Difficulties implementing a mental health guideline: an exploratory investigation using psychological theory. Implementation Science 2007, 2:8.

13. Amemori M, Michie S, Korhonen T, Murtomaa H, Kinnunen TH: Assessing implementation difficulties in tobacco use prevention and cessation counselling among dental providers. Implementation Science 2011, 6:50

14. Brotherton JML, Leask J, Jackson C, McCaffery K, Trevena L: National survey of general practitioners experience of delivering the national human papillomavirus vaccination program. Sex Heal 2010, 7(3):291-298.

15. Clarkson JE, Ramsay CR, Eccles MP, Eldridge S, Grimshaw JM, Johnston M, Michie S, Treweek S, Walker A, Young L, Black I, Bonetti D, Cassie H, Francis J, MacKenzie G, MacPherson L, McKee L, Pitts N, Rennie J, Stirling D, Tilley C, Torgerson C, Vale L: The translation research in a dental setting (TRiaDS) programme protocol. Implementation Science 2010, 5:57.

16. Dyson J, Lawton R, Jackson C, Cheater F: Does the use of a theoretical approach tell us more about hand hygiene behaviour? the barriers and levers to hand hygiene. J Infect Prev 2011, 12(1):17-24.

17. Edwards P, Felix L, Harris J, Ferguson E, Free C, Landon J, Lock K, Michie S, Miners A, Murray E: Assessing the effectiveness and cost effectiveness of adaptive e-Learning to improve dietary behaviour: Protocol for a systematic review. BMC Public Health 2010, 10:200.

18. Godin G, Bélanger-Gravel A, Eccles M, Grimshaw J: Healthcare professionals' intentions and behaviours: A systematic review of studies based on social cognitive theories. Implementation Science 2008, 3:36.

19. Guillaumie L, Godin G, Vézina-Im L-: Psychosocial determinants of fruit and vegetable intake in adult population: a systematic review. Int $\rfloor$ Behav Nutr Phys Activ 2010, 712

20. Zhu DQ, Norman IJ, While AE: The relationship between doctors' and nurses' own weight status and their weight management practices: a systematic review. Obes Rev 2011, 12(6):459-469.

21. Jacobs N, De Bourdeaudhuij I, Thijs H, Dendale P, Claes N: Effect of a cardiovascular prevention program on health behavior and BMI in highly educated adults: a randomized controlled trial. Patient Educ Couns 2011, 85(1):122-126

22. Judah G, Aunger R, Schmidt W, Michie S, Granger S, Curtis V: Experimental pretesting of hand-washing interventions in a natural setting. Am J Public Health 2009, 99(SUPPL. 2):S405-S411.

23. Ivers NM, Tu K, Francis J, Barnsley J, Shah B, Upshur R, Kiss A, Grimshaw JM, Zwarenstein M: Feedback GAP: Study protocol for a cluster-randomized trial of goal setting and action plans to increase the effectiveness of audit and feedback interventions in primary care. Implementation Science 2010, 5:98

24. Weiner B: An attributional theory of achievement motivation and emotion. Psychol Rev 1985, 92(4):548-573.

25. Stevens G: Bias in attributions of positive and negative behavior in children by school psychologists, parents, and teachers. Percept Mot Ski 2002, 50(3):1283-1290.

26. Karasek R: Job Content Questionnaire and user's quide: University of Massachusetts. Department of Work Environment Massachusetts: Lowell, MA: 1985

27. Rogers EM: Diffusion of Innovations. Glencoe: Free Press; 1962.

28. Foy R, MacLennan G, Grimshaw J, Penney G, Campbell M, Grol R: Attributes of clinical recommendations that influence change in practice following audit and feedback. J Clin Epidemiol 2002, 55(7):717-722.

29. Kitson AL, Rycroft-Malone J, Harvey G, McCormack B, Seers K, Titchen A: Evaluating the successful implementation of evidence into practice using the PARiHS framework: theoretical and practical challenges. Implementation Science 2008, 31.

30. Damschroder L, Aron DC, Keith RE, Kirsh SR, Alexander JA, Lowery JC Fostering implementation of health services research findings into practice: a consolidated framework for advancing implementation science. Implementation Science 2009, 4:50.

31. Dombrowski SU, Sniehotta FF, Avenell A, Coyne JC: Current issues and future directions in Psychology and Health: towards a cumulative 
science of behaviour change: do current conduct and reporting of behavioural interventions fall short of best practice? Psychol Health 2007 22(8):869-874.

32. Craig P, Dieppe P, Macintyre S, Michie S, Nazareth I, Petticrew M, Medical Research Council G: Developing and evaluating complex interventions: the new Medical Research Council guidance. BMJ 2008, 337:a1655.

33. Cane J, O'Connor D, Michie S: Validation of the theoretical domains framework for use in behaviour change and implementation research. Implementation Science 2012, 7:x.

doi:10.1186/1748-5908-7-35

Cite this article as: Francis et al.: Theories of behaviour change

synthesised into a set of theoretical groupings: introducing a thematic series on the theoretical domains framework. Implementation Science 2012 7:35. 